\title{
Mismatch Risk, Government Guarantees, and Financial Instability: The Case of the U.S. Pension System*
}

\author{
Zvi Bodie \\ Boston University
}

\begin{abstract}
Failure to take account of the mismatch between the assets in defined-benefit pension plans (primarily equities) and the liabilities (deferred fixed annuities) has long been a major unrecognized source of financial instability. The underfunding problems now facing state and local government pension plans and the Pension Benefit Guaranty Corporation are a direct consequence of this conceptual and practical failure. Yet the source of the problems and the policies needed to correct these problems remain unrecognized by many, if not most, mainstream economists. This essay uses option-pricing theory to show how to efficiently manage the pension mismatch risk and the consequences of failure to do so.
\end{abstract}

JEL Codes: E, G, H.

\section{Introduction}

Ben Friedman was one of the first scholars whom I had the good fortune to befriend during my doctoral studies at the Massachusetts Institute of Technology (MIT) in the early 1970s. I had come to MIT with an MS degree in economics from the Hebrew University, where I studied monetary economics under Don Patinkin. At MIT I quickly came under the influence of Franco Modigliani, who was working with James Tobin, Albert Ando, and Lawrence Klein on econometric policy models of the U.S. economy with a disaggregated financial sector. Ben Friedman too was building his own econometric models of the bond and credit markets to analyze the effects of monetary policy on fund flows and yield spreads.

\footnotetext{
${ }^{*}$ Copyright (C) 2012 Zvi Bodie. Author contact: www.ZviBodie.com.
} 
When we first met, Ben was starting his academic career as assistant professor at Harvard. He was also continuing to work as a parttime economic advisor for Morgan Stanley. Ben recruited me to work on a project for Morgan Stanley that was to have a profound effect on my subsequent career. The project involved long-term corporate bonds that had been issued in the late 1960s. Interest rates had subsequently fallen in the early 1970s, but the prices of these bonds did not rise very much, and the spread between corporate bonds and U.S. Treasury bonds widened. This was because corporate bonds all contained an embedded option permitting the issuing corporations to call them long before they matured (after five years in the case of utility bonds and after ten years in the case of industrial bonds). In recognition of this fact, investors would calculate the yield-to-firstcall date as well as the yield to maturity on these bonds. The head of the bond desk at Morgan Stanley wanted to find a more precise way to take account of the embedded call option.

All this was happening at the same time that the Chicago Board Options Exchange was coming into existence, and Black, Scholes, and Merton were discovering the option-pricing model at MIT. After the Morgan Stanley consulting project ended, Ben suggested a joint research study that ultimately resulted in an article we published in the Journal of Political Economy, "Interest Rate Uncertainty and the Value of Bond Call Protection," in February 1978. I subsequently headed down the path of the new approach to financial economics that was born in the 1970s at MIT - applying dynamic replication and option-pricing principles to public policy issues in pensions and retirement.

Like Ben, I have always believed that financial economics and macroeconomics should be friends. They should enrich and complement each other. In this brief essay in honor of Ben, I will discuss some insights from modern financial economics that ought to be incorporated into macroeconomics, even at the introductory level. They relate to the analysis of asset-liability mismatch risk and the efficient management of guarantees, and have important implications for the current debate about capital adequacy of financial institutions and government as lender of last resort.

In my work on pensions, I have shown that failure to take account of the mismatch between the assets in defined-benefit pension plans (primarily equities) and the liabilities (deferred fixed annuities) has 
long been a major unrecognized source of financial instability. The underfunding problems now facing state and local government pension plans and the Pension Benefit Guaranty Corporation (PBGC) are a direct consequence of this conceptual failure. Yet the source of the problems and the policies needed to correct them remain unrecognized by many, if not most, mainstream economists.

In the remainder of this essay, I will first summarize the principles for the efficient management of financial guarantees. Then I will demonstrate how option-pricing theory is used to determine the amount of capital required to insure such guarantees when there is a mismatch between assets and liabilities. Finally, I will conclude with some observations on how failure to properly manage government guarantees can lead to financial instability and crisis. The specific focus throughout will be on defined-benefit pensions.

\section{Principles for Managing Financial Guarantees ${ }^{1}$}

Regardless of whether it is run by a private-sector organization or a government agency, there are certain principles that must be followed if a system of guarantees is to remain viable. Functionally, guarantees are insurance policies that oblige the guarantor to make the promised payment if the insured pension fund fails to do so. The economic loss to the guarantor is equal to the difference between the promised payment and the price received from the sale of the assets that are available from the fund as collateral for this obligation. This difference is called the "shortfall." All assets of the fund that the guarantor has recourse to seize will be called "collateral" assets, even if they are not formally pledged and segregated. For the guarantee activity to be sustainable without recourse to subsidies from other sources, premiums charged for the guarantees must be large enough to cover both actuarial loss experience and operating costs.

The basic methods that any guarantor (whether private sector or government) has to manage its business on a sound basis are as follows:

\footnotetext{
${ }^{1}$ This section is based on Merton and Bodie (1992).
} 
- Funding Restrictions: Set standards for the full funding of promised benefits (i.e., "capital adequacy") and act swiftly to limit losses when these funding standards are violated (i.e., avoid "forbearance").

- Matching Restrictions: Require the insured entity to hedge its insured liabilities by matching the market-risk exposure of its assets to its insured liabilities.

- Pricing: Set a premium schedule for the guarantee commensurate with the guarantor's exposure to the risk of a shortfall.

- Transparency: Require disclosure of information about the insured institution's assets and liabilities in a format that is relevant to evaluating the guarantor's exposure to shortfall risk.

The methods substitute for each other in varying degrees; hence, there is room for trade-offs among them. With all methods, the guarantor must monitor the market values of the insured liabilities and the assets securing them on a regular basis. The length of time permitted for making up a funding deficit is a key parameter to be set in determining the optimal trade-off among methods.

For example, let us set the premium equal to the cost of a single guarantee. For simplicity, assume that there are no operating costs. If the value of collateral assets, $V$, exceeds the promised payments, $B$, the guarantor keeps the premium and pays nothing. But if the value of assets is less than the promised payments, the guarantor must pay the difference, $B-V$. The guarantor's maximum profit is equal to the premium plus interest earned from investing the premium prior to payment of losses or expiration of the guarantee. This maximum profit is diminished by the shortfall or loss experience from issuer defaults. The guarantor's profit function is thus given by

$$
P(1+r)-\max [0, B-V],
$$

where $P$ is the premium and $r$ is the interest rate.

The guarantor bears the full downside risk of the collateral assets. It does not, however, participate in the upside gains that an owner of those assets would receive. Because of this asymmetry, the guarantor's expected loss is an increasing function of the volatility (i.e., standard deviation) of the difference between the promised payment $B$ and the asset value $V$. Therefore, to sustain themselves as viable 
economic entities without cross-subsidies from other insured institutions or from taxpayer funds, the guarantor must charge a premium that is directly related to the magnitude of the potential shortfall. This magnitude depends directly on the length of time permitted to make up a funding deficit.

If a funding shortfall must be made up immediately, as is the case with margin loans made by brokerage firms and margin requirements of organized futures exchanges, then the guarantor can charge a premium that is relatively small. It need only cover the costs of monitoring the system. But typically pension funds are allowed relatively long periods in which to make up a funding shortfall.

\section{Pension Mismatch Risk and Capital Adequacy in the Light of Option Theory ${ }^{2}$}

In this section I consider the trade-off between capital adequacy and matching restrictions using option-pricing theory as the analytical framework. The tighter the matching restrictions, the smaller the amount of buffer capital required to maintain the integrity of the pension promise. Many in the investment industry hold the view that a diversified equity portfolio is an effective hedge against the pension liability when the investment horizon is long term. However, using option-pricing theory, it becomes evident that the cost of insuring a pension liability collateralized with equities actually increases with the length of time required to make up a funding deficit.

Assume a defined-benefit plan sponsor is faced with the obligation to pay a fixed amount as a pension benefit $T$ years from now, and it will not have to make up any funding deficits until then. It fully funds its obligation by contributing to the pension fund an amount equal to the present value of the promised benefit. It can invest in an immunized default-free bond portfolio maturing in $T$ years earning a certain risk-free rate of interest. If instead the sponsor invests in a stock portfolio, then there is a risk of a shortfall at time $T$.

\footnotetext{
${ }^{2}$ This section is based on Bodie (1995).
} 
The basis for the proposition that stocks are less risky in the long run appears to be the observation that the longer the time horizon, the smaller the probability of a shortfall. If the ex ante mean rate of return on stocks exceeds the risk-free rate of interest, it is indeed true that the probability of a shortfall declines with the length of the investment time horizon. For example, suppose the rate of return on stocks is log-normally distributed with a risk premium of 8 percent per year and an annualized standard deviation of 20 percent. With a time horizon of only one year, the probability of a shortfall is 34 percent, whereas at twenty years that probability is only 4 percent.

But the probability of a shortfall is a flawed measure of risk because it ignores how large the potential shortfall might be. It is easy to see this point if we assume that stock returns follow a simple "random walk." In any one-year period, assume the rate of return on stocks can take only one of two values - either +20 percent or -20 percent - independent of its past history. Consider the worst possible outcome for time horizons of increasing length. For a oneyear horizon one can lose 20 percent of the initial investment, for a two-year period 36 percent, and for a twenty-year period as much as 99 percent. Using the probability of a shortfall as the measure of risk, no distinction is made between a loss of 20 percent or a loss of 99 percent.

If it were true that stocks are less risky in the long run, then the cost of insuring against earning less than the risk-free rate of interest should decline as the maturity of the pension obligation increases. But the opposite is true.

To see this, define the cost of shortfall insurance, $P$, as the additional amount of money one has to add at the investment starting date to assure that at the maturity date the pension portfolio will have a value at least as great as it would have earning the risk-free interest rate. Thus, for each dollar insured against a shortfall, the total amount actually invested at the starting date is $\$ 1+P$.

To find $P$, we use modern option-pricing methodology. Insurance against shortfall risk is effectively a put option. The put is of the European type (i.e., it can only be exercised at the expiration date), and it expires in $T$ years. The put's exercise price is the insured value of the portfolio. If at the expiration date $T$ years from now the portfolio's value exceeds its insured value, then the put expires 
worthless. If, however, there is a shortfall, then the put's payoff is equal to the shortfall.

Because we are insuring a pension obligation that grows at the risk-free interest rate, the exercise price of the put equals the price of the underlying stock portfolio compounded at the risk-free $T$-year interest rate. Therefore the put-call parity theorem tells us that the price of the put equals the price of the corresponding call.

To show that the value of the put increases with $T$, we could use any option-pricing model based on the condition that the financial markets do not allow anyone to earn risk-free arbitrage profits. Because it is so compact and so widely used in practice, we will use the Black-Scholes formula. In our special case, the formula reduces to a relatively simple form. Moreover, with no loss of generality, we can express the price of the put as a fraction of the price of the stock.

$$
\begin{aligned}
& \frac{P}{S}=N\left(d_{1}\right)-N\left(d_{2}\right) \\
& d_{1}=\frac{\sigma \sqrt{T}}{2} \\
& d_{2}=\frac{-\sigma \sqrt{T}}{2},
\end{aligned}
$$

where $S=$ price of the stock, $T=$ time to expiration of the option in years, $\mathrm{s}=$ standard deviation of the annualized continuously compounded rate of return on the stock, and $N(d)=$ the probability that a random draw from a standard normal distribution is less than $d$.

Note that $P / S$ is independent of the risk-free interest rate; it depends only on $s$ and $T$. Table 1 and figure 1 show the result of applying the formula to compute $P / S$ assuming the annualized standard deviation of stock returns is .2. The cost of the insurance rises with $T$, the term of the insurance. For a one-year term, the cost is 8 percent of the investment. For a ten-year term, it is 25 percent, and for a fifty-year term it is 52 percent.

As the term grows without limit, the cost of the insurance approaches 100 percent of the investment.

Some observers of the stock market have claimed that stock returns do not follow a random walk in the long run. Rather, they argue, the behavior of stock returns is best characterized as a meanreverting process. It is mean reversion in stock returns, they say, 
Table 1. Cost of Shortfall Insurance as a Function of Time Horizon

\begin{tabular}{|c|c|}
\hline $\begin{array}{c}\text { Length of Time Horizon } \\
\text { in Years }\end{array}$ & $\begin{array}{c}\text { Cost of Insurance as Percentage } \\
\text { of Investment }\end{array}$ \\
\hline 1 & 7.98 \\
5 & 17.72 \\
10 & 24.84 \\
\hline
\end{tabular}

Notes: The table was derived using the Black-Scholes formula with $s=.2$ per year. The cost of the insurance is independent of the risk-free rate.

Figure 1. Probability of a Shortfall and Cost of Insurance as a Function of Time

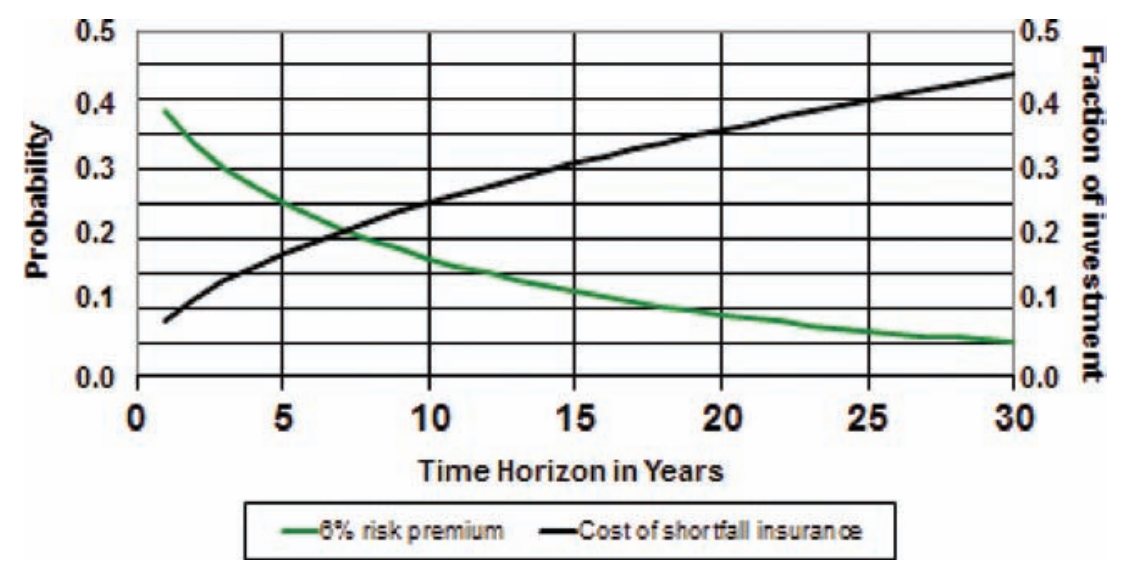

that is the reason stocks are less risky for investors with a long time horizon.

But figure 1 is valid for mean-reverting processes too. The reason is that arbitrage-based option-pricing models, such as the BlackScholes or binomial models, are valid regardless of the process for the mean. They are based on the law of one price and the condition of no-arbitrage profits. Investors who disagree about the mean rate of return on stocks, but agree about the variance, will therefore agree about the option price.

For the relation depicted in figure 1 to be invalid, mean reversion is not enough. Stock prices would have to behave just like the 
price of a $T$-period zero-coupon bond that converges towards the bond's face value as the horizon date approaches. In other words, stocks would have to be indistinguishable from the risk-free asset for a $T$-period horizon.

The policy parameters that a guarantor can in principle control are (i) the required funding ratio, (ii) the speed with which a pension fund must make up for a shortfall below the required funding ratio, (iii) the required degree of matching between the pension liabilities and the assets backing them, and (iv) the premium charged for the insurance. Table 1 and figure 1 are relevant to assessing the relationship among these parameters.

$T$ is the time interval permitted to make up a funding shortfall. For a given $T$ and asset-liability mismatch, the cost of the guarantee $P$ represents the minimum required buffer. Thus, the shorter the time interval and the better the match, the lower the required buffer. If the pension sponsor invests the pension assets in common stocks or other types of equity securities rather than in fixed-income securities that immunize the guaranteed benefits, then the exposure of the government to a potential shortfall is increased. The required funding ratio must therefore be increased.

For the guarantee system to be viable, volatility need not be reduced to zero, but it does have to be known (or at least bounded) and not subject to significant unilateral change by the insured pension plan. If the insured pension-plan sponsor can unilaterally change the composition of the asset portfolio, then the government faces a problem of moral hazard since some sponsors will have an incentive to not fund their plans adequately and increase the risk of their assets.

\section{The Experience of the PBGC}

The PBGC insures the pension benefits of Americans covered by private defined-benefit pension plans. Since defined-benefit plans in the United States are backed by the corporations that sponsor them, the PBGC is actually a reinsurer. If the pension assets are insufficient to cover the pension liabilities, it is up to the corporate plan sponsor to make up the shortfall. It is only when the corporate sponsor goes bankrupt with insufficient assets to pay the benefits promised to employees that the PBGC takes it over and makes up the shortfall. 
There is a cap on the PBGC-insured benefit, so that highly compensated employees of firms that go bankrupt do not typically get full benefits.

By law, the PBGC is supposed to finance all of its operations from three sources: (i) the premiums it collects from companies that still sponsor defined-benefit plans, (ii) the assets it recovers from terminated underfunded plans, and (iii) the interest, dividends, and capital gains it earns on its accumulated reserves.

The current system overcharges sponsors of healthy plans in order to subsidize the ailing ones. But in the United States employers are not required to offer any kind of occupational pension plan, and companies that do sponsor plans can choose a defined-contribution (DC) design rather than the traditional defined-benefit (DB) plan. In recent years, virtually all new pension plans have been DC plans, and many sponsors of DB plans have switched to the DC plan design.

For the PBGC, this creates a problem of adverse selection. Wellfunded plans have an incentive to terminate their defined-benefit plans to avoid being "taxed" through high actuarially unfair premiums to bail out underfunded plans of financially weak sponsors. The result is that only sick and undercharged firms will be left in the insurance pool. Thus we have a classic case of the law of unintended consequences: Insurance designed to strengthen the traditional pension system winds up accelerating its demise.

As a result of a combination of falling interest rates and falling stock prices during the period 2000 to 2003, many defined-benefit pension plans went from being well funded to underfunded. As a result of a wave of bankruptcies of steel companies and airlines with severely underfunded pension plans, the PBGC found itself facing a massive cumulative deficit.

In 2006 the U.S. government enacted the Pension Protection Act to address these problems. It raised premiums, tightened funding rules, and improved the measurement and reporting of corporate pension liabilities. But it did nothing to take account of the asset-liability mismatch in setting PBGC premiums or to restrict the exposure of the PBGC by requiring closer matching of pension assets to liabilities. Indeed, the Pension Protection Act does not even recognize that there is a mismatch problem.

The experience of the PBGC suggests that it can be difficultperhaps impossible - for the U.S. government to manage its system 
of pension guarantees by adjusting the price it charges to properly reflect the risk posed by a mismatch between pension assets and liabilities or by requiring closer matching of assets to liabilities. The only genuine alternative left is to require a larger buffer of risk capital for plan sponsors that expose the guarantor to greater mismatch risk. However, that alternative also seems to be blocked. The most underfunded pension plans are precisely those of corporations that are under financial distress. The government has consistently excused such corporations from making cash contributions to fund their pension plans for fear of driving them into bankruptcy.

\section{Conclusion}

The destabilizing feedback loop caused by government guarantees of too-big-to-fail financial institutions, moral hazard, forbearance, and ever bigger government bailouts is familiar to analysts of the U.S. banking system. It is less familiar, but no less pernicious, in the case of the pension system. In the case of pensions, however, the vicious cycle is less transparent because of the fallacious belief that the risk of equities goes away in the long run. Until there is a recognition that equities are not a match for the fixed liabilities of defined-benefit pension liabilities, it will remain a serious source of financial instability for the U.S. economy.

\section{References}

Bodie, Z. 1995. "On the Risk of Stocks in the Long Run." Financial Analysts Journal 51 (3): 18-22.

Merton, R. C., and Z. Bodie. 1992. "On the Management of Financial Guarantees." Financial Management 21 (4). 